\title{
Ut på tur
}

Det er påske, og hva er vel mer norsk enn å legge ut på skitur på fjellet? Men i hvor god form er det norske folk? I 1923 undersøkte man fysisk yteevne blant 3600 rekrutter gjennom øvelser som løp, høyde- og lengdehopp, ballkast m.m. I Tidsskriftet ble undersøkelsen presentert av Carl Schiøtz (1877-1938) og Georg Waaler (1895-1983) (Tidsskr Nor Lægeforen 1927; 47: 861-8).

\section{Norske rekrutters fysiske ydeevne. Idrætsundersøkelser 1923.}

Av dr.med. Carl Schiøtz og prosektor Georg Waaler.

(...)

Hensigten med rekrutprøverne var nu av samme art.

1. Undersøkelse av vore soldaters ydeevne i og for sig, videre sammenligning mellem præstationerne ved rekrutskolens begyndelse og slutning, videre sammenligning mellem de forskjellige landsdeler. Antropometriske studier av høide, vegt og vegt-høideforhold.

2. Utarbeidelse av normer efter samme princip som for skolealderen, anvendelige og ansporende for alle, ikke bare for «s t je r n e r». (En sammenligning av egen præstation med rekorder passer bare eller væsentlig for de faa utvalgte. En sammenligning med gj en e ms n itsværdi e r og andre statististiske data er derimot oplysende for alle). Videre: midler til at sammenligne forskjellige avdelinger og landsdeler samt midler til at kontrollere «allround-evnen» og dermed motarbeide specialisteriet, som ikke tjener den sunde harmoniske utvikling. Dette sker bedst ved et paa rent teoretisk statistisk grundlag utarbeidet pointsystem.

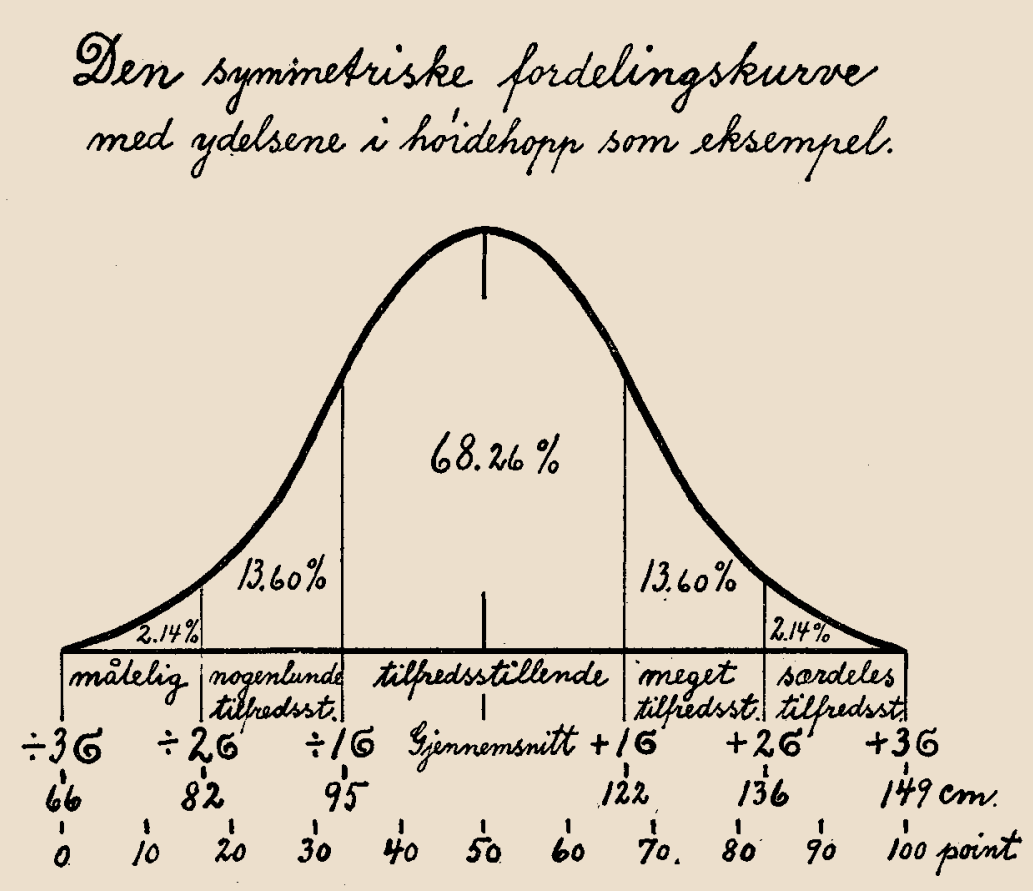

